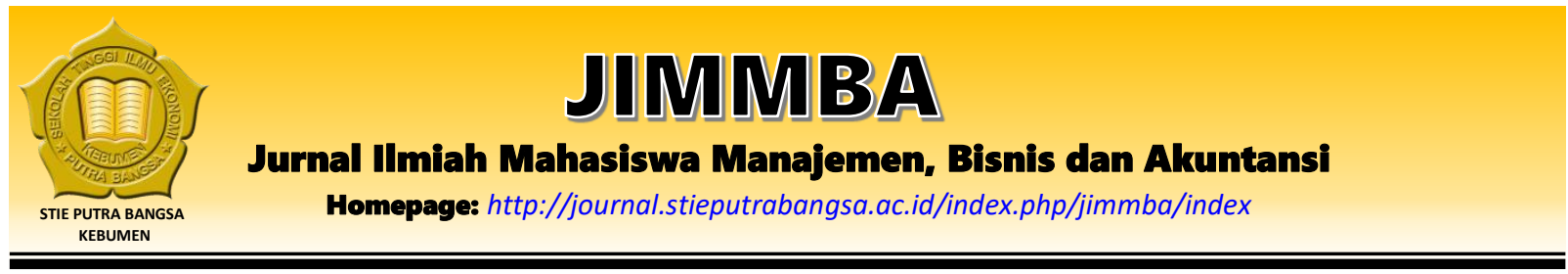

\title{
Pengaruh ROE, TVA, dan DER Terhadap Return Saham pada Perusahaan Sub Sektor Perbankan dengan PBV sebagai Variabel Intervening
}

\author{
Tri Wahyuningsih ${ }^{1}$, Aris Susetyo ${ }^{2}$ \\ ${ }^{1}$ Sekolah Tinggi Ilmu Ekonomi Putra Bangsa \\ ${ }^{2}$ Sekolah Tinggi Ilmu Ekonomi Putra Bangsa \\ Email: wahyuningsihtri05@gmail.com
}

\section{ARTICLE INFO}

Article History:

Received: March $4^{\text {th }} 2020$

Accepted: March 5 2020

Published: April 30th 2020

Keywords:

Return on Equity, Trading

Volume Activity, Debt to

Equity Ratio, Price Book

Value, Return Saham

\section{ABSTRACT}

Penelitian ini bertujuan untuk mengetahui pengaruh Return On Equity (ROE), Trading Volume Activity (TVA), dan Debt To Equity Ratio (DER) terhadap Return Saham melalui Price Book Value (PBV) sebagai variabel intervening pada perusahaan perbankan yang terdaftar di LQ45 periode 20162019. Populasi penelitian ini adalah semua perusahaan perbankan yang terdaftar di LQ45 periode 2016-2019. Teknik pengambilan sampel menggunakan metode purposive sampling dan menghasilkan jumlah sampel sebanyak 5 perusahaan perbankan. Sumber data yang digunakan dalam penelitian ini adalah data sekunder triwulan. Alat analisis yang digunakan adalah analisis jalur dibantu dengan SPSS versi 22. Hasil pembuktian hipotesis terhadap PBV menunjukkan bahwa ROE dan DER memiliki pengaruh signifikan terhadap PBV sedangkan TVA tidak memiliki pengaruh terhadap PBV. Hasil pembuktian hipotesis terhadap Return Saham menunjukkan bahwa ROE dan DER memiliki pengaruh signifikan terhadap Return Saham sedangkan TVA dan PBV tidak memiliki pengaruh terhadap Return Saham. Hasil analisis menggunakan analisis jalur menunjukkan bahwa ROE, dan DER tidak terdapat pengaruh tidak langsung terhadap Return Saham melalui PBV. Sedangkan TVA terdapat pengaruh tidak langsung terhadap Return Saham melalui PBV. Berdasarkan nilai $\mathrm{R}^{2}$ menunjukkan bahwa kontribusi antar variabel pada model pertama sebesar $46,9 \%$ sisanya sebesar $53,1 \%$ dipengaruhi oleh variabel lain diluar model dan pada model kedua sebesar $19,7 \%$ sisanya sebesar $80,3 \%$ dipengaruhi oleh variabel diluar model. 


\section{Pendahuluan}

Investasi merupakan penanaman asset atau dana yang dilakukan oleh sebuah perusahaan atau perorangan untuk jangka waktu tertentu dengan harapan mendapat imbal balik yang lebih besar di masa mendatang. Investasi yang banyak diminati yakni investasi saham. Tercatat jumlah investor saham setiap tahunnya mengalami peningkata. Tahun 2017 jumlah investor sebanyak 628.491 SID, tahun 2018 sebanyak 852.240 SID, dan pertanggal 28 November 2019 telah mencapai 1.089.987 SID. Investasi banyak diminati karena i investasi saham lebih menarik dibandingkan investasi lainnya karena investasi saham memiliki modal yang relative kecil, investasi saham jadi menguntungkan jika diperuntukkan jangka panjang.

Return saham merupakan hasil yang diperoleh dari investasi (Hartono, 2003:109). Return saham adalah tingkat pengembalian saham yang diharapkan oleh investor melalui suatu portofolio. Return saham bisa menjadi suatu indikator keberhasilan suatu perusahaan. Keinginan investor dalam berinvestasi yakni mendapkan return yang tinggi, akan tetapi saat ini, return di Indonesia memberikan hasil negatif.

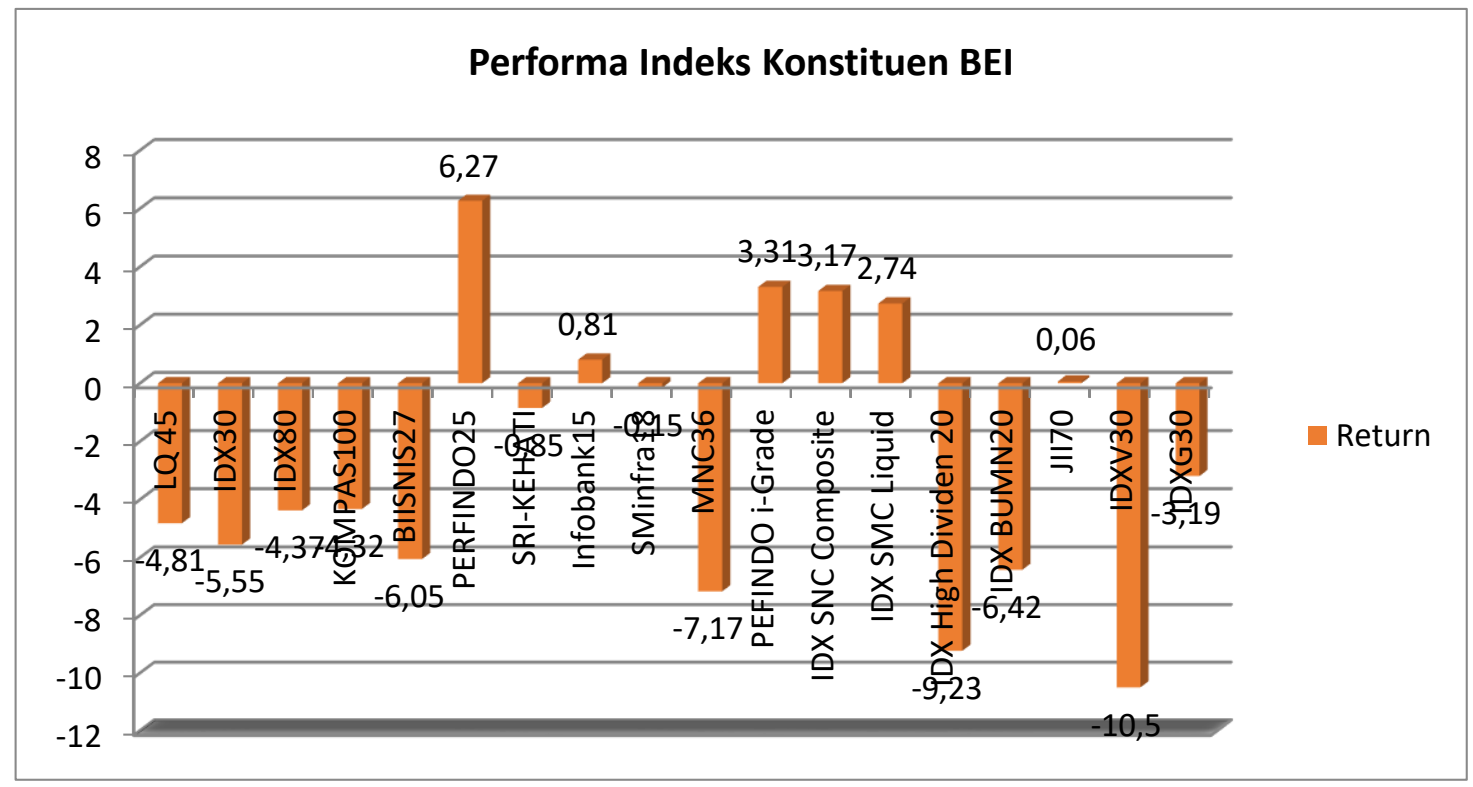

Sumber: Kontan edisi 4 Oktober 2019

Gambar 1. Garfik Performa Indeks

Terlihat dari grafik diatas menunjukan bahwa dari 19 indeks, 13 diantaranya memberikan return negatif dan sisanya memberikan return yang positif. Penurunan return indeks konstituen yang melemah disusul dengan kinerja Indeks Harga Saham Gabungan (IHSG). IHSG saat ini memberikan imbal hasil atau return minus. Dari 11 negara di Asia, dua diantaranya memberikan return yang negatif termasuk Indonesia, yakni return minus $1.52 \%$.

Investasi yang memberikan return relatif besar adalah sektor-sektor yang paling produktif di pasar. Salah satu sektor yang paling diminati adalah sektor perbankan. Tahun 2019 sektor perbankan menopang laju positif IHSG yang naik 1,98\% . Beberapa saham di sektor ini yang menguat seperti saham PT Bank Rakyat Indonesia (Persero) Tbk (BBRI) tercatat naik 3,66\% atau sebesar 150 poin menjadi Rp 4.250 per saham, serta PT Bank Central Asia Tbk (BBCA) naik 2,21\% atau 650 poin menjadi Rp 30.050 per saham. Kemudian, PT Bank Mandiri (Persero) Tbk (BMRI) juga naik 1,38\% atau 100 poin menjadi Rp 7.350 per saham, PT Bank 
Negara Indonesia (Persero) Tbk (BBNI) naik 0,64\% atau 50 poin menjadi Rp 7.875 per saham, dan PT Bank Tabungan Negara (Persero) Tbk (BBTN) naik 3,6\% atau 80 poin menjadi Rp 2.300 per saham.

\section{Kajian Teori dan Telaah Literatur Signaling theory}

Signaling Theory merupakan teori yang berkaitan dengan informasi yang menunjukkan adanya informasi bagi masyarakat atau calon investor mengenai manajemen perusahaan. Informasi yang lengkap, relevan, akurat, dan tepat waktu sangat diperukan oleh investor dipasar modal. Informasi ini digunakan sebagai alat analisis untuk mengambil keputusan berinvestasi. Informasi yang disajikan pada hakekatnya berupa keterangan, catatan atau gambaran baik keadaan masa lalu, saat ini maupun masa mendatang bagi keberlangsungan suatu perusahaan dan efek pasarnya.

\section{Pecking order theory}

Menurut Febriana dan Yulianto (2017) pecking order theory merupakan teori yang menyatakan permasalahan utama keputusan struktur modal perusahaan adalah informasi yang tidak simetris diantara manajer dan investor mengenai kondisi internal perusahaan. Berdasarkan asumsi teori ini, perusahaan akan menggunakan pendanaan eksternal berupa utang yang memiliki risiko rendah dibandingkan dengan penerbitan sekuritas saham. Teori pecking order memprediksi adanya hubungan negatif antara keuntungan dan rasio hutang. Selanjutnya, teori pecking order juga menunjukkan bahwa struktur modal perusahaan yang diamati memiliki hubungan yang positif dengan ukuran, pertumbuhan dan kekayaan atau aset perusahaan.

Alasan utama mengapa teori pecking order ditafsirkan memiliki hubungan negatif antara rasio hutang dan keuntungan adalah bahwa pembayaran dividen dianggap erat kaitannya dengan keuntungan dan besarnya hutang. Oleh karena itu, perusahaan akan mempunyai pilihan untuk membayar hutang yang akan menyebabkan penurunan rasio hutang dengan meningkatnya keuntungan. Artinya bahwa, apabila keuntungan meningkat maka kemampuan perusahaan untuk membiayai investasinya dari hasil keuntungan akan meningkat. Di sisi lain, meningkatnya keuntungan akan meningkatkan pertumbuhan perusahaan.

\section{Saham}

Saham meupakan tanda bukti penyertaan kepemilikian modal/dan pada suatu perusahaan (Fahmi, 2013 : 36). Saham dipergunakan sebagai salah satu alat untuk mencari tambahan dana dengan tujuan ingin memberikan profit yang tinggi bagi pemakainya, serta memiliki dampak keputusan yang bersifat berkelanjutan (sustainable). Investor membeli saham karena mereka mengharapkan tingkat pengembalian (return) yang baik atas investasi yang mereka lakukan tanpa suatu risiko yang cukup berarti.

\section{Return saham}

Return adalah hasil yang diperoleh oleh para investor dari tindakan investasi. Lestari, dkk (2016) return saham adalah suatu tingkat pengembalian saham yang diharapkan atas investasi yang dilakukan dalam saham atau beberapa kelompok saham melalui suatu portofolio. Semakin menarik return yang diberikan perusahaan, maka semakin besar juga 
niat investor dalam menamkan modalnya (Artik, 2009). Komponen return terdiri dari Yield (mencerminkan aliran kas atau pendapatan yang diperoleh secara periodic dari suatu investasi), dan Capital Gain/Loss (kenaikan/penurunan harga suatu surat berharga ang memberikan keuntungan/kerugian bagi investor.

$$
\mathrm{R}_{\mathrm{t}}=\frac{\mathrm{Pt}-(\mathrm{Pt}-1)}{\mathrm{Pt}-1}
$$

\section{Price book value}

Price to Book Value adalah rasio yang bertujuan menunjukkan perbandingan harga saham terhadap nilai buku saham (Almiyah, 2016). Keunggulan price book value yakni 1) Nilai buku mempunyai ukuran intuitif yang relatif stabil yag dapat dibandingkan dengan harga pasar, 2) Nilai buku memberikan standar akuntansi yang konsisten untuk semua perusahaan, 3) Perusahaan-perusahaan dengan earning negatif yang tidak bisa dinilai dengan menggunakan Price Earnings Ratio dapat dievaluasi menggunakan Price Book Value

Harga Per Lembar Saham

Nilai Buku Per Lembar Saham

\section{Return on equity}

Harahap (2007) mendefinisikan return on equity (ROE) merupakan perbandingan antara laba bersih suatu emiten dengan modal yang dimiliki. Rasio ini mengkaji sejauh mana suatu perusahaan mempergunakan sumber daya yang dimiliki untuk mampu memberikan laba atas equitas (Fahmi, 2017: 98). Return on equity merupkan salah satu rasio profitabilitas. Rasio Profitabilitas merupakan kemampuan perusahaan memperoleh laba dalam hubungannya dengan penjualan, total aktiva maupun modal sendiri (Sartono, 2001: 122).

$$
\frac{\text { Laba Setelah Pajak }}{\text { Modal Sendiri }} \times 100 \%
$$

\section{Trading volume activity}

Trading Volume Activity atau volume perdagangan adalah rasio antara jumlah lembar saham yang diperdagangkan pada waktu tertentu terhadap jumlah lembar saham yang beredar pada waktu tertentu (Husnan, 2009:63). Naiknya volume perdagangan merupakan kenaikan aktivitas jual beli oleh para investor di bursa. Semakin meningkat volume permintaan dan penawaran suatu saham, semakin besar pengaruhnya terhadap fluktuasi harga saham di bursa (Nasir dan Mirza, 2011).

$$
\text { TVAi, } t=\frac{\text { Jumlah saham i yang diperdagangkan pada waktu } t}{\text { Jumlah saham i yang beredar pada waktu } t}
$$




\section{Debt to Equity Ratio}

Menurut Kasmir (2016: 157) Debt to Equity Ratio adalah rasio yang digunakan untuk menilai hutang dengan ekuitas. Rasio ini berguna untuk mengetahui jumlah dana yang disediakan peminjam (kreditor) dengan pemilik perusahaan atau untuk mengetahui jumlah modal sendiri yang dijadikan untuk jaminan utang. Kemampuan suatu perusahaan untuk membayar hutang menunjukkan leverage suatu perusahaan.

$$
\text { Debt to Equity Ratio }=\frac{\text { Total Liabilities }}{\text { Total Equity }}
$$

\section{Hipotesis}

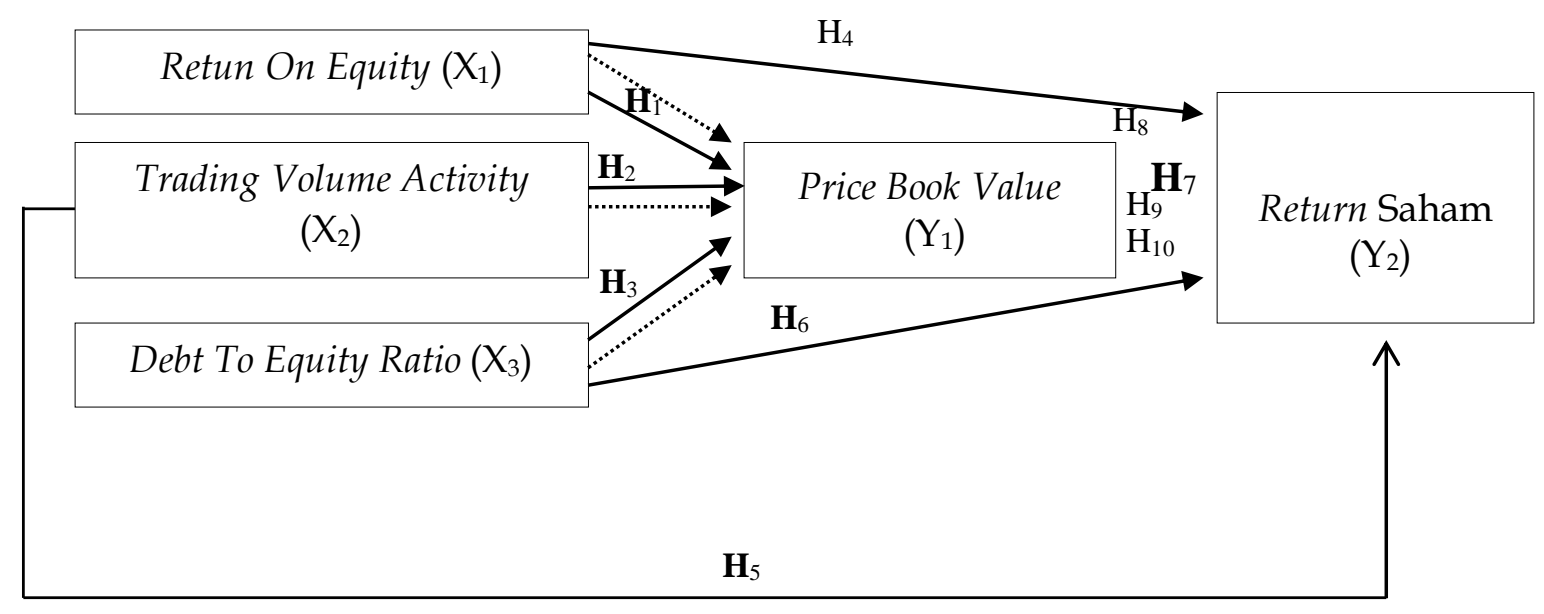

\section{Gambar 2. Kerangka hipotesis}

$\mathbf{H}_{1}$ : Return On Equity berpengaruh secara langsung terhadap Price Book Value

$\mathbf{H}_{2}$ : Trading Volume Activity berpengaruh secara langsung terhadap Price Book Value

$\mathbf{H}_{3}$ : Debt To Equity Ratio berpengaruh secara langsung terhadap Price Book Value

$\mathbf{H}_{4}$ : Return On Equity berpengaruh secara langsung terhadap Return Saham

$\mathbf{H}_{5}$ : Trading Volume Activity berpengaruh secara langsung terhadap Return Saham

$\mathbf{H}_{6}$ : Debt To Equity Ratio berpengaruh secara langsung terhadap Return Saham

$\mathbf{H}_{7}$ : Price Book Value berpengaruh berpengaruh secara langsung terhadap Return Saham

$\mathbf{H}_{8}$ : Return On Equity berpengaruh secara tidak langsung terhadap Return Saham melalui Price Book Value

$\mathbf{H}_{9}$ : Trading Volume Activity berpengaruh secara tidak langsung terhadap Return Saham melalui Price Book Value

$\mathbf{H}_{10}$ : Debt To Equity Ratio berpengaruh secara tidak langsung terhadap Return Saham melalui Price Book Value

\section{Metode Penelitian}

\section{Sampel dan Data}

Pengambilan sampel dalam penelitian ini dengan menggunakan metode purposive sampling. Adapun kriteria sample yang digunakan dalam penelitian ini yakni perusahan perbankan yang konsisten terdaftar di Indeks LQ 45 periode 2016-2019. 
Penelitian ini menggunakan data kuantitatif yang berbetuk angka. Sumbe data yang digunakan dalam penelitian ini adalah data sekunder yang berupa jurnal, penelitian terdahulu, artikel, yahoo finance, buku, laporan keuangan dari Bursa Efek Indonesia periode 2016-2019.

Metode pengumpulan data dalam penelitian ini adalah dengan metode dokumentasi, yakni engan mengumpulkan, mencatat, dan mengkaji data sekunder yang berupa laporan keuangan.

\section{Pengukuran variabel}

Pengukuran variabel penelitian dengan menggunakan Return on Equity, Trading Volume Activity, Debt to Equity Ratio sebagai variabel independen. Pengukuran Price Book Value untuk variabel intervening, dan Return Saham dalam pengukuran variabel dependen.

\section{Hasil dan Pembahasan}

\section{Statistik Deskriptif}

Menurut Ghozali (2018: 19) Statistik Deskriptif memberikan gambaran atau deskripsi suatu data yang dilihat dari nilai rata-rata (mean), standar deviasi, varian, maksimum, minimum, sum, range, kurtosis dan skewness (kemencengan distribusi).

Tabel 1. Uji descriptive statistics

\begin{tabular}{lcrrrr}
\hline & N & Minimum & Maximum & Mean & Std. Deviation \\
\hline ROE & 70 & .0282 & .1830 & .087315 & .0442661 \\
TVA & 70 & .0003 & .0106 & .002019 & .0018330 \\
DER & 70 & 4.201 & 11.396 & 6.33413 & 2.010765 \\
PBV & 70 & .84 & 4.69 & 2.2281 & 1.06248 \\
RETURN & 70 & -.355 & .347 & .05451 & .117209 \\
Valid N (listwise) & 70 & & & & \\
\hline
\end{tabular}

Sumber : Olah data SPSS 22, 2019

Dari tabel 1 dapat dilihat bahwa $\mathrm{N}$ menunjukkan angka 70 yang memiliki arti bahwa jumlah data dalam penelitian ini sebanyak 70 yang diperoleh dari 5 Perusahaan Perbankan periode 2016-2019. Dari hasil analisis di atas, standar deviasi tertinggi adalah DER yaitu sebesar 2.010765. Hal tersebut menunjukkan bahwa DER memiliki keberagaman sampel yang paling besar dibandingkan dengan variabel yang lainnya. Untuk standar deviasi paling rendah yaitu pada variabel TVA sebesar 0.0018330 .

Price Book Value (Y1) memiliki nilai rata-rata 2.2281 dengan standar deviasi 1.06248. PBV memiliki nilai minimum 0.84 pada Bank Tabungan Negara (BBTN) pada Triwulan 2 tahun 2019. Nilai maksimum sebesar 4.69 pada Bank Central Asia (BBCA) pada Triwulan 2 tahun 2019.

Return Saham (Y2) memiliki nilai rata-rata 0.05451 dengan standar deviasi 0.117209. Return Saham memiliki nilai minimum -0.355 pada Bank Tabungan Negara (BBTN) pada Triwulan 2 tahun 2018. Nilai maksimum sebesar 0.347 pada Bank Tabungan Negara (BBTN) pada Triwulan 1 tahun 2016.

Return On Equity (X1) memiliki nilai rata-rata 0.087315 dengan nilai standar deviasi 0.0442661. ROE memiliki nilai minimum 0.0282 pada Bank Rakyat Indonesia (BBRI) pada 
Triwulan 1 tahun 2017. Nilai maksimum sebesar 0.1830 yang dimiliki Bank Central Asia (BBCA) pada Triwulan 4 tahun 2016.

Trading Volume Activity (X2) memiliki nilai rata-rata 2.1869 dengan nilai standar deviasi 0.0018330 . TVA memiliki nilai minimum 0.0003 pada Bank Central Asia (BBCA) pada Triwulan 1 tahun 2019. Nilai maksimum sebesar 0.1830 yang dimiliki oleh Bank Central Asia (BBCA) pada Triwulan 2 tahun 2019.

Debt to Equity Ratio (X3) memiliki nilai rata-rata 6.33413 dengan nilai standar deviasi 2.010765. DER memiliki nilai minimum 4.201 pada Bank Central Asia (BBCA) pada Triwulan 1 tahun 2019. Nilai maksimum sebesar 11.396 yang dimiliki oleh Bank Tabungan Negara (BBTN) pada Triwulan 1 tahun 2016.

\section{Uji t dan uji analisis jalur}

Uji parsial (uji t) merupakan pengujian yang menunjukkan seberapa jauh pengaruh satu variabel independen secara satu per satu dalam menerangkan variasi variabel dependen.

Analisis jalur (path analysis) merupakan perluasan dari analisis regresi linear berganda, atau dengan kata lain analisis jalur adalah penggunaan analisis regresi untuk menaksir hubungan kausalitas antar variabel (model casual) yang telah ditetapkan sebelumnya (Ghozali, 2018: 245).

Tabel 2. Hasil uji koefisien jalur persamaan 1

\begin{tabular}{llrrrrr}
\hline & \multicolumn{2}{c}{$\begin{array}{l}\text { Unstandardized } \\
\text { Coefficients }\end{array}$} & \multicolumn{2}{c}{$\begin{array}{c}\text { Standardized } \\
\text { Coefficients }\end{array}$} & & \\
\cline { 2 - 5 } Model & \multicolumn{1}{c}{ B } & Std. Error & Beta & \multicolumn{1}{c}{$\mathrm{t}$} & Sig. \\
\hline 1 & (Constant) & 2.612 & .255 & & 10.222 & .000 \\
& SQRT_X1 & .939 & .410 & .209 & 2.292 & .025 \\
& SQRT_X2 & -3.032 & 1.903 & -.149 & -1.592 & .116 \\
& SQRT_X3 & -.522 & .087 & -.568 & -6.007 & .000 \\
\hline
\end{tabular}

a. Dependent Variable: SQRT_Y1

Sumber: Olah Data SPSS 22, 2019

Persamaan strukturalnya adalah sebagai berikut :

$\mathrm{Y} 1=0.209 \mathrm{X}_{1}-0.149 \mathrm{X}_{2}-0.568 \mathrm{X}_{3}+€_{1}$

Tabel 3. Hasil uji koefisien jalur persamaan 2

\begin{tabular}{|c|c|c|c|c|c|}
\hline \multirow[b]{2}{*}{ Model } & \multicolumn{2}{|c|}{$\begin{array}{l}\text { Unstandardized } \\
\text { Coefficients }\end{array}$} & \multirow{2}{*}{$\begin{array}{c}\text { Standardized } \\
\text { Coefficients } \\
\text { Beta }\end{array}$} & \multirow[b]{2}{*}{$\mathrm{t}$} & \multirow[b]{2}{*}{ Sig. } \\
\hline & B & Std. Error & & & \\
\hline (Constant) & -.119 & .255 & & -.467 & .645 \\
\hline SQRT_X1 & .584 & .257 & .314 & 2.270 & .028 \\
\hline SQRT_X2 & -2.081 & 1.329 & -.226 & -1.567 & .124 \\
\hline SQRT_X3 & .142 & .068 & .358 & 2.094 & .042 \\
\hline SQRT_Y1 & -.015 & .074 & -.036 & -.200 & .842 \\
\hline
\end{tabular}

a. Dependent Variable: SQRT_Y2

Sumber: Olah Data SPSS 22, 2019 
Persamaan struktural 2 adalah sebagai berikut :

$\mathrm{Y}_{2}=0.314 \mathrm{X}_{1}-0.226 \mathrm{X}_{2}+0.358 \mathrm{X}_{3}-0.036 \mathrm{Y}_{1}+€_{1}$

Berdasarkan tabel 2 dapat dilihat bahwa nilai signifikan return on equity sebesar 0.025 . Dengan nilai sinifikan $0.025<0.05$ maka dapat disimpulkan bahwa Return on Equity (X1) memiliki pengaruh dan signifikan terhadap Price Book Value (Y1). Nilai signifikan trading volume activity sebesar 0.116. Dengan nilai sinifikan $0.116>0.05$, maka dapat disimpulkan bahwa Trading Volume Activity (X2) tidak memiliki pengaruh terhadap Price Book Value (Y1). Nilai signifikan debt to equity ratio sebesar $0.000<0.05$. Dengan nilai signifikan $0.000<0.05$, maka dapat disimpulkan bahwa Debt to Equity Ratio (X3) memiliki pengaruh signifikan terhadap Price Book Value (Y1).

Berdasarkan tabel 3 dapat dilihat bahwa return on equity memiliki nilai signifikan sebesar 0.025. Dengan nilai signifikan $0.025<0.05$, maka dapat disimpulkan bahwa Return on Equity (X1) memiliki pengaruh dan signifikan terhadap Return Saham (Y2). Trading volume activity memiliki nilai signifikan sebesar 0.121 . Dengan nilai signifikan $0.121>0.05$, maka dapat disimpulkan bahwa Trading Volume Activity (X2) tidak memiliki pengaruh terhadap Return Saham (Y2) dengan nilai koefisien -0.219. Debt to equity ratio memiliki nilai signifikan sebesar 0.010. Dengan nilai signifikan $0.010<0.05$. maka dapat disimpulkan bahwa Debt to Equity Ratio (X3) memiliki pengaruh signifikan terhadap Return Saham (Y2). Price book value memiliki nilai signifikan sebesar 0.586. Dengan nilai signifkan $0.586>0.05$, maka dapat disimpulkan bahwa Price Book Value (Y1) tidak memiliki pengaruh terhadap Return Saham (Y2) dengan nilai koefisien -0.036.

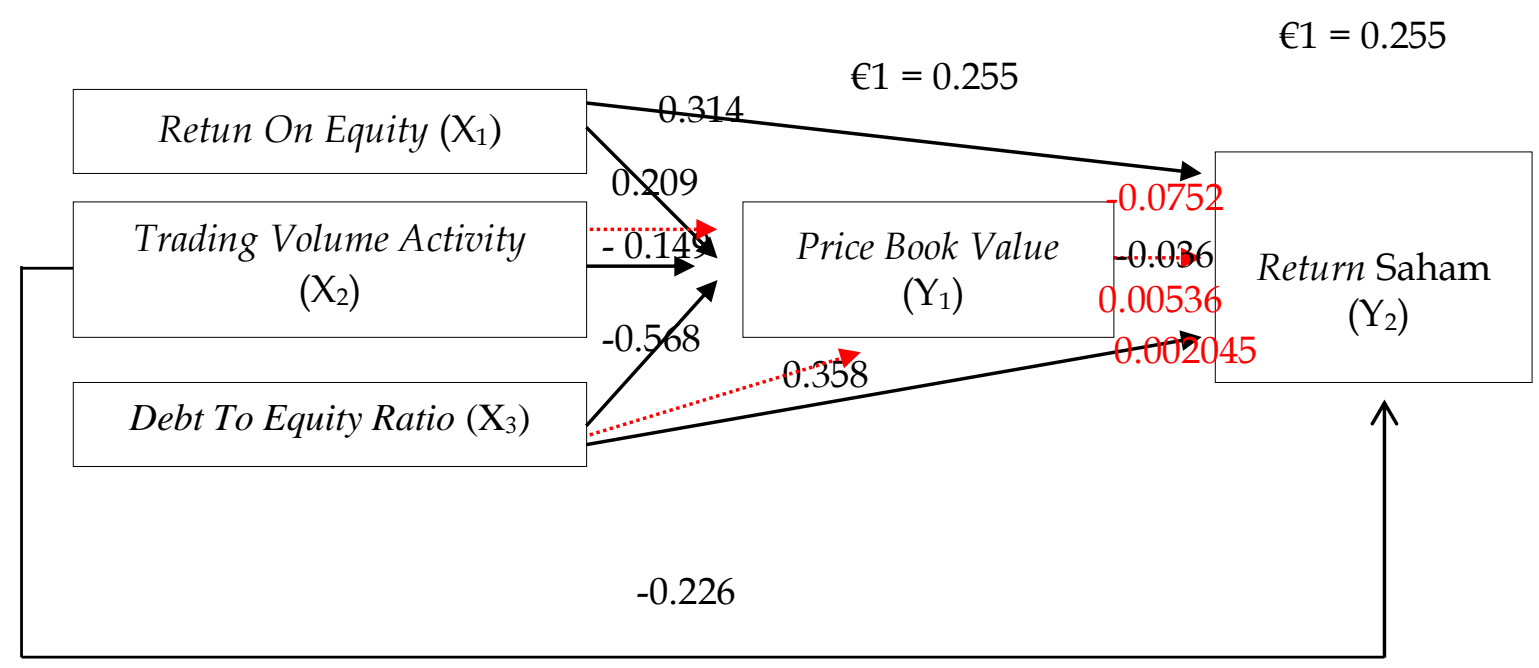

Gambar 3. Hasil analisis jalur

Berdasarkan hasil analisis jalur pada Gambar 3 dapat dilihat bahwa pengaruh langsung Return on Equity (X1 Terhadap Y2) sebesar 0.314, pengaruh tidak langsung (X1 terhadap Y2 melalui Y1) sebesar -0.0075, dan pengaruh total sebesar 0.173. Trading Volume Activity (X2 Terhadap Y2) sebesar -0.226, pengaruh tidak langsung (X2 terhadap Y2 melalui Y1) sebesar 0.00536, dan pengaruh total sebesar -0.185. Berdasarkan analisis jalur dapat dilihat bahwa pengaruh Debt to Equity Ratio (X3 Terhadap Y2) sebesar 0.358, pengaruh tidak langsung (X3 terhadap Y2 melalui Y1) sebesar 0.02045, dan pengaruh total sebesar -0.604 . 


\section{Uji koefisien determinasi}

Tabel 4. Hasil uji koefisien determinasi persamaan 1

Model Summary ${ }^{b}$

\begin{tabular}{lrrrr}
\hline Model & $\mathrm{R}$ & $\begin{array}{c}\mathrm{R} \\
\text { Square }\end{array}$ & $\begin{array}{c}\text { Adjusted R } \\
\text { Square }\end{array}$ & $\begin{array}{l}\text { Std. Error of } \\
\text { the Estimate }\end{array}$ \\
\hline 1 & $.685^{\mathrm{a}}$ & .469 & .445 & .25205 \\
\hline
\end{tabular}

a. Predictors: (Constant), SQRT_X3,SQRT_X1,SQRT_X2

b. Dependent Variable: SQRT_Y1

Sumber : Olah Data SPSS 22, 2019

Berdasarkan tabel 4 dapat dilihat bahwa nilai R Square sebesar 0.469 , hal ini berarti variabel return on equity, trading volume activity dan debt to equity ratio memiliki pengaruh terhadap price book value sebesar $46.9 \%$. Sedangkan sisa $(100 \%$ - 46.9\% ) sebesar $53.1 \%$ dipengaruhi oleh variabel yang lain di luar model.

Tabel 5. Hasil uji determinasi persamaan 2 Model Summary ${ }^{b}$

\begin{tabular}{|c|c|c|c|c|}
\hline Model & $\mathrm{R}$ & R Square & $\begin{array}{l}\text { Adjusted R } \\
\text { Square }\end{array}$ & $\begin{array}{l}\text { Std. Error of the } \\
\text { Estimate }\end{array}$ \\
\hline 1 & $.444^{\mathrm{a}}$ & .197 & .127 & .13267 \\
\hline
\end{tabular}

Berdasarkan tabel 5 dapat dilihat bahwa nilai R Square sebesar 0.197, hal ini berarti variabel return on equity, trading volume activity, debt to equity ratio dan price book value memiliki pengaruh terhadap return saham sebesar $19.7 \%$. Sedangkan sisa $(100 \%-19.6 \%)$ sebesar $80.3 \%$ dipengaruhi oleh variabel yang lain di luar model.

\section{Pengaruh return on equity terhadap price book value}

Return On Equity (X1) memiliki pengaruh secara langsung dan signifikan terhadap Price Book Value (Y1). Hasil penelitian ini sejalan dengan penelitian yang dilakukan oleh Dwikirana dan Prasetiono tahun 2016 yang menyatakan bahwa Return On Equity berpengaruh positif terhadap Price Book Value. Artinya, ketika ROE menunjukkan peningkatan hal tersebut akan direspon sebagai signal positif oleh investor. Tingginya rasio ROE menunjukkan prospek perusahaan yang semakin baik karena berarti adanya potensi peningkatan keuntungan yang diperoleh perusahaan. Semakin tinggi keuntungan maka para investor tertarik untuk berinvestasi. Apabila terdapat kenaikkan permintaan saham suatu perusahaan, maka secara tidak langsung akan menaikkan harga pasar per lembar saham di pasar modal (Amiliyah, 2016). Dengan naiknya harga pasar perlembar saham maka akan semakin tinggi pula nilai PBVnya.

\section{Pengaruh trading volume activity terhadap price book value}

Trading Volume Activity (X2) tidak memiliki pengaruh terhadap Price Book Value (Y1). Trading Volume Activity yang tinggi tidak mempengaruhi tingginya nilai Price Book Value. Hasil penelitian ini sejalan dengan penelitian yang dilakukan oleh Amiliyah tahun 2016 yang menyatakan bahwa Volume Perdagangan Saham berpengaruh negatif dan tidak signifikan 
terhadap terhadap Price Book Value.Dalam hal ini investor kurang mempertimbangkan Trading Volume Activity karena besar kecilnya jumlah Trading Volume Activity tidak dapat mempengaruhi harga saham dalam suatu perusahaan. Sehingga investor kurang mempertimbangkan Trading Volume Activity dalam menentukan rasio Price Book Value.

\section{Pengaruh debt to equity ratio terhadap price book value}

Debt to Equity Ratio (X3) pengaruh secara langsung signifikan dengan korelasi kuat terhadap Price Book Value (Y1). Hasil penelitian ini sejalan dengan penelitian yang dilakukan oleh Hasibuan, dkk tahun 2016 yang menyatakan bahwa Debt to Equity Ratio berpengaruh dan signifikan terhadap terhadap Price Book Value. Debt To Equity Ratio yang tinggi menunjukkan bahwa hutang perusahaan semakin besar dibandingkan total modal sendiri sehingga berdampak semakin besar beban perusahaan terhadap pihak luar. Pada perusahaan perbankan, semakin tinggi hutang kredit) maka semakin baik pula perusahaan tersebut. Artinya bahwa masyarakat menaruh kepercayaan tinggi pada perusahaan tersebut. Semakin banyak hutang akan menyebabkan semakin tingginya investor untuk menanamkan sahamnya, sehingga semakin tinggi pula permintaan saham. Semakin tinggi permintaan akan menaikkan harga saham, sehingga nilai PBV juga meningkat.

\section{Pengaruh return on equity terhadap return saham}

Return On Equity (X1) berpengaruh langsung signifikan dengan korelasi cukup kuat terhadap Return Saham (Y2). Hasil penelitian ini sejalan dengan penelitian yang dilakukan oleh Carlo tahun 2014 yang menyatakan bahwa Return On Equity berpengaruh positif dan signifikan terhadap Return Saham. ROE menggambarkan besarnya perolehan atas modal yang ditanamkan atau kemampuan modal sendiri untuk menghasilkan keuntungan bagi pemegang saham preferen dan saham biasa. Nilai ROE yang tinggi menunjukan semakin tinggi laba yang dihasilkan perusaahaan, sehingga akan berdampak pada peningkatkan ekuitas pemegang saham. Hal ini dapat membuktikan bahwa meningkatnya nilai ROE maka mempengaruhi peningkatan return yang diterima investor. Para investor mengindikasikan perusahaan yang mampu memberikan Return Saham dapat dilihat dari tingginya nilai ROE..

\section{Pengaruh trading volume activity terhadap return saham}

Trading Volume Activity (X2) tidak memiliki pengaruh dengan korelasi sangat lemah terhadap Return Saham (Y2). Hasil penelitian ini sejalan dengan penelitian yang dilakukan oleh Yusra tahun 2019 yang menyatakan bahwa Trading Volume Activity tidak berpengaruh terhadap tingkat Return Saha . Semakin tinggi Trading Volume Activity tidak mempengaruhi tingginya Return Saham yang diperoleh oleh investor. Karena Trading Volume Activity yang tinggi tidak mempengaruhi tingginya harga saham. Investor dalam menanamkan modalnya tidak melirik besar kecilnya nilai TVA karena TVA mengindikasikan keadaan pasar saham di bursa saham. Selain itu tinggi rendahnya TVA tidak dapat berimbas pada return yang akan diperoleh investor, karena TVA hanya menjadi indikator keadaan pasar (ramai/sepi).

\section{Pengaruh debt to equity ratio terhadap return saham}

Debt to Equity Ratio (X3) memiliki pengaruh langsung dan signifikan dengan korelasi sangat lemah terhadap Return Saham (Y2). Hasil penelitian ini sejalan dengan penelitian yang dilakukan oleh Nalurita (2015) yang menyatakan bahwa Debt to Equity Ratio berpengaruh positif dan signifikan terhadap Return Saham. Perusahaan dengan DER yang tinggi menunjukkan bahwa perusahaan tersebut menggunakan modal pendaan eksternal yang tinggi. Perusahaan memerlukan banyak pendanaa untuk mendanai operasional perusahaan. Sesuai dengan teori saham yang menyatakan bahwa high risk-hgh return dimana risiko dari suatu perusahaan ditandai dengan tingkat DER yang dimiliki. Beberapa investor memilih sifat suka mengambil risiko akan cenderung saham-saham yang memiliki DER yang tinggi. 
Menurut teori MM yang menyatakan bahwa perusahaan akan semakin baik apabila menggunakan hutang semakin besar. Ketika perusahaan menggunakan hutang, dimana hutang tersebut merupakan hutang jangka panjang, maka akan menyebabkan perusahaan tersebut membayar bunga. Sehingga pajak yang dibayarkan oleh perusahaan yang menggunakan hutang akan lebih kecil dan return saham akan meningkat.

\section{Pengaruh price book value terhadap return saham}

Price Book Value (Y1) tidak memiliki pengaruh dan korelasi sangat lemah terhadap Return Saham (Y2). Hasil penelitian ini sejalan dengan penelitian yang dilakukan oleh Mulya dan Turisna tahun 2016 yang menyatakan bahwa Price Book Value tidak berpengaruh terhadap Return Saham. Semakin besar nilai Price Book Value (PBV) maka belum tentu Return yang diperoleh investor besar. Tidak adanya pengaruh antara Price Book Value dengan Return Saham dikarenakan besar kecilnya Return Saham tidak berdasarkan besar kecilnya nilai Price Book Value. Dalam hal ini Price Book Value bukan lagi menjadi tolak ukur investor untuk menanamkan sahamnya dengan tujuan mendapatkan return yang tinggi. Karena kekhawatiran investor ketika membeli saham nantinya harga semakin menurun.

\section{Pengaruh return on equity terhadap return saham melalui price book value}

Berdasarkan hasil pengujian menunjukkan bahwa hubungan yang sebenarnya adalah Return On Equity lebih efektif berpengaruh langsung terhadap Return Saham daripada melalui Price Book Value. Hasil tersebut dapat disimpulkan bahwa Price Book Value bukan merupakan variabel intervening dalam hubungan antara Return On Equity dengan Return Saham. Tingkat Return On Equity secara langsung dapat mempengaruhi besar kecilnya Return Saham yang diperoleh investor.

\section{Pengaruh trading volume activity terhadap return saham melalui price book value}

Berdasarkan hasil pengujian tersebut menunjukkan bahwa hubungan yang sebenarnya adalah pengaruh tidak langsung, karena nilai koefisien langsung (-0.226) lebih kecil dari nilai koefisien tidak langsung (0.00536). Rasio Trading Volume Activity lebih efektif berpengaruh secara tidak langsung terhadap Return Saham melalui Price Book Value.

\section{Pengaruh debt to equity ratio terhadap return saham melalui price book value}

Berdasarkan hasil pengujian menunjukkan bahwa hubungan yang sebenarnya adalah rasio Debt to Equity Ratio lebih efektif berpengaruh langsung terhadap Return Saham daripada melalui Price Book Value. Hasil tersebut dapat disimpulkan bahwa Price Book Value bukan merupakan variabel intervening dalam hubungan antara Debt to Equity Ratio dengan Return Saham. Tingkat Debt to Equity Ratio secara langsung dapat mempengaruhi besar kecilnya Return Saham yang diperoleh investor. Tingginya rasio leverage akan mempengaruhi minat investor terhadap saham perusahaan.

\section{Penutup dan Saran}

\section{Simpulan}

Hasil pembuktian hipotesis terhadap Price Book Value menunjukkan bahwa variabel Trading Volume Activity tidak berpengaruh signifikan terhadap variabel Price Book Value, variabel Return On Equity dan Debt to Equity Ratio berpengaruh signifikan terhadap Price Book Value. Hasil pembuktian hipotesis terhadap Return Saham menunjukkan bahwa Trading Volume Activity tidak berpengaruh signifikan terhadap variabel Return Saham, variabel Return On Equity dan Debt to Equity Ratio berpengaruh signifikan terhadap Return Saham. Hasil analisis dengan menggunakan analisis jalur menunjukkan bahwa variabel Trading Volume Activity tidak memiliki hubungan langsung terhadap Return Saham melainkan harus melalui 
variabel Price Book Value. Variabel Return On Equity dan Debt to Equity Ratio tidak terdapat pengaruh tidak langsung terhadap Return Saham melalui variabel Price Book Value.

\section{Keterbatasan}

1. Jumlah sampel penelitian tidak lebih dari 100 sampel dan tergolong sedikit karena periode yang diteliti mulai dari 2016-2019

2. Nilai koefisien determinasi variabel intervening dari hasil penelitian ini sangat rendah yaitu hanya sebesar $19.7 \%$ sehingga kemampuan variabel PBV menjadi variabel intervening sangat kecil.

3. Penelitian ini terbatas pada faktor-faktor internal yakni return on equity, trading volume activity, debt to equity ratio, dan price book value.

\section{Referenasi}

Amiliyah, M. (2018). Pengaruh Return on Equity, Debt to Equity Ratio, Current Ratio, dan Volume Perdagangan Saham Terhadap Nilai Perusahaan pada Emiten Pertambangan di Bursa Efek Indonesia Periode 2011-2013. Manajerial, 3(2), 46-58.

Carlo, M. A. (2014). Pengaruh return on equity, dividend payout ratio, dan price to earnings ratio pada return saham. E-Jurnal Akuntansi, 150-164.

Fahmi, I. (2017). Pengantar Pasal Modal. Panduan Bagi Para Akademisi Dan Praktisi Bisnis Dalam Memahami Pasar Modal Indonesia. Bandung: Alfabeta.

Febriana, D., \& Yulianto, A. (2017). Pengujian Pecking Order Theory di Indonesia. Management Analysis Journal, 6(2), 153-165.

Ghozali, I. (2018). Aplikasi Analisis Multivariate dengan Program IBM SPSS 25. Edisi 9. Semarang: Universitas Diponegoro

Hartono, J. (2003). Teori Portofolio dan Analisis Investasi. Edisi 3. Yogyakarta: BPFEYogyakarta.

Husnan, S. (2009). Dasar-dasar Teori Portofolio \& Analisis Sekuritas. Yogyakarta: UPP STIM YKPN.

Kasmir. (2016). Analisis Laporan Keuangan Lainnya. Jakarta: Raja Grafindo Persada.

Mulya, Y. \& Turisna R. (2016)._Pengaruh Kinerja Keuangan Terhadap Return Saham Pada Perusahaan Sub Sektor Otomotif yang Terdaftar di Bursa Efek Indonesia. JIMFE (Jurnal Ilmiah Manajemen Fakultas Ekonomi), 2(1), 41-52.

Nalurita, F. (2017). The effect of profitability ratio, solvability ratio, market ratio on stock return. Business and Entrepreneurial Review, 15(1), 73-94.

Nasir, A., \& Mirza, A. (2011). Pengaruh Nilai Kurs, Inflasi, Suku Bunga Deposito dan Volume Perdagangan Saham Terhadap Return Saham Pada Perusahaan Perbankan yang Terdaftar di Bursa Efek Indonesia. Jurnal Ekonomi, 19(04).

Yusra, M. (2019). Pengaruh Frekuensi Perdagangan, Trading Volume, Nilai Kapitalisasi Pasar, Harga Saham, dan Trading Day Terhadap Return Saham Pada Perusahaa Kosmetik dan Keperluan Rumah Tangga di Bursa Efek Indonesia. Jurnal Akuntansi dan Keuangan, 7(1), 65-67 